\title{
The Effect of Anxiety on Pregnant Women during the Covid-19 Pandemic
}

\section{Pengaruh Kecemasan pada Ibu Hamil di Masa Pandemi Covid-19}

Solichatin $^{1 *}$, Yefi Marliandiani ${ }^{2}$

${ }^{1 *}, 2$ Universitas PGRI Adi Buana Surabaya, Jawa Timur, Indonesia

\begin{tabular}{l}
\hline ARTICLE INFORMATION \\
\hline Received: 30 April 2021 \\
Revised: 26 May 2021 \\
Accepted: 29 May 2021 \\
KEYWORD \\
\hline
\end{tabular}

Level anxiety, pregnant mothers, COVID-19 pandemic.

Kecemasan; Ibu hamil; Pandemi COVID-19

\section{CORRESPONDING AUTHOR}

\section{Solichatin}

Jl. Dukuh Menanggal XII Surabaya

solichatin@unipasby.ac.id

\section{DOI}

https://doi.org/10.36456/embrio.v13i1.3689

\section{A B S T R A C T}

Pregnant mothers typically will experience both physical and psychological changes that naturally come alongside their physical and hormonal changes. The spread and transmission of SARS-CoV-2 is very rapid such that it is now considered as a pandemic. This pandemic force government to release several policies such as mask-mandate, handwashing-mandate, and crowd limitation to reduce the spread of the virus on everyone, including expecting mothers. Due to the pandemic, a lot of social interaction must be limited, including the routine pregnancy medical examination. In other hand, expecting mothers tends to be more easily anxious due to many reasons that can compromise their fetus and their own health. The objective of this research is to obtain a qualitative description of mothers' anxiousness in relation to the COVID-19 pandemic situation. Google forms filled by the respondents were mainly used as tool to collect descriptive data in this research. The data was collected at Restu Pregnancy Clinic at Pakis Malang. 30 respondents who were doing ante-natal-care (ANC) are chosen by total sampling technique from the clinic. The data collected was then analyzed by frequency table and percentage. The instrument used was the perinatal anxiety screening scale (PASS). The result obtained indicated that most of the expecting mothers in the Restu Pregnancy Clinic are having light-medium level of anxiety level during COVID-19 pandemic situation.

Ibu hamil akan menjumpai perubahan psikis dan fisik yang secara natural sejalan dengan perubahan hormonalnya. Sebaran virus SARSCoV-2 yang terbilang cepat dan memasuki semua negara maka ditetapkan sebagai pandemi COVID-19. Pandemi mengharuskan pemerintah Indonesia juga untuk menyampaikan aturan-aturan seperti pemakaian masker, mencuci tangan dan menghindari berkerumun guna meminimalkan sebaran virus yang berdampak pada psikis semua orang tak terkecuali ibu hamil dalam menjalani kehamilannya. Kehidupan sosial banyak terpengaruh demikian juga jadwal kontrol kehamilan yang menyesuaikan situasi dan kondisi. Kecemasan ibu hamil pencetusnya karena beberapa hal. Yang akan berpengaruh pada kesehatan ibu dan janinnya. sehingga diperlukan informasi yang tepat bagi ibu hamil. Tujuan penelitian ini untuk mengetahui tingkat kecemasan ibu hamil di masa COVID-19 sedang menjadi hal yang perlu perhatian kita semua. Desain penelitian adalah deskriptif dengan menyebarkan formular secara online kepada ibu hamil. Kegiatan ini dilaksanakan di BPM Restu, Pakis Malang. Pesertanya merupakan ibu hamil yang tercatat melakukan pemeriksaan kehamilan di BPM Restu, sejumlah 30 orang dengan teknik total sampling. Tigapuluh ibu hamil mengirim formulir yang telah diisi dan data dianalisis menggunakan tabel frekuensi dan persentase. Dalam penelitian ini alat ukur menggunakan the perinatal anxiety screening scale (PASS). Setelah penelitian usai didapatkan hasil ibu hamil di BPM Restu, Pakis Malang saat berjangkitnya COVID-19, Sebagian besar berada dalam tingkat kecemasan dengan skala ringan-sedang. 


\section{Pendahuluan}

Beberapa hal dapat mengakibatkan ketidaknyamanan pada ibu hamil bisa jadi karena kehamilan adalah pengalaman pertama, atau kehamilan kedua namun dengan riwayat berbeda, Persalinan adalah hal asing, juga perubahan hormonal yang dialami. Beberapa penelitian menyampaikan laporan yang menyebabkan kegelisahan pada ibu hamil tidak jarang terpicu oleh kondisi ekonomi, jadwal pekerjaan, serta rasa kecemasan tentang kehamilan ataupun persalinan yg akan dilalui (Nurhasanah, 2020). Hasil penelitian yang telah dilakukan di Irlandia, menyebutkan tingkat kecemasan ibu hamil menunjukkan peningkatan lebih dari 50,67\%, hal tersebut berhubungan dengan ketidaktahuan tentang serba serbi kehamilan dan perawatan bayi mereka setelah melahirkan (Corbett et al., 2020). Kecemasan ibu hamil sebelum persalinan sangat rentan akan terjadinya abortus, persalinan prematur, berat bayi saat lahir yang kecil dan nilai Apgar yang rendah (Phoswa \& Khaliq, 2020).

COVID-19 sebagai pandemi yang melanda dunia dan tak tekecuali Indonesia, disamping sudah menimbulkan terpuruknya ekonomi juga menimbulkan korban jiwa yang tidak sedikit, serta semua sisi kehidupan sosial yang terdampak (Presiden RI, 2020). Pelayanan kesehatan ibu dan anak pun juga dibatasi baik untuk kunjungan pemeriksaan, konsultasi ataupun kualitas layanannya, salah satu contohnya kelas pelatihan ibu hamil seperti senam hamil, yoga dan lain-lain sangat dibatasi dalam rangka mengurangi paparan wabah ini (Direktorat Kesehatan Keluarga, 2020). Kondisi dan situasi yang kurang menguntungkan tersebut akan sangat mempengaruhi kondisi masyarakat tak terkecuali ibu hamil yang akan memicu masalah Kesehatan mental salah satunya trauma saat kehamilan (Saputri et al., 2020)

Sebuah penelitian melaporkan tentang kecemasan dan kondisi depresi ibu hamil lebih tinggi setelah pandemi COVID-19 daripada sebelum COVID-19, salah satunya dengan keinginan melukai diri sendiri (Wu et al., 2020). Kondisi yang bahaya selama kehamilan dapat disebabkan oleh hal tersebut, di mana kondisi ibu dan janin dapat terpengaruh (Durankuş \& Aksu, 2020). Angka kejadian COVID-19 di Provinsi Jawa Timur menempati urutan pertama secara Nasional (Gugus Tugas COVID-19 Nasional, 2020). Malang menempati urutan ketiga setelah Surabaya dan Sidoarjo, berikutnya disusul Banyuwangi Tujuan dari studi kali ini adalah untuk mengetahui tingkat kecemasan ibu hamil di BPM Restu Pakis Malang.

\section{Metode}

Penelitian ini menggunakan desain penelitian deskriptif. Populasi target dalam penelitian adalah ibu hamil yang tercatat melakukan pemeriksaan kehamilan di BPM Restu, sejumlah 30 orang. Pengambilan sampel menggunakan teknik total sampling, yaitu semua ibu hamil yang tercatat melakukan ante natal care (ANC) di BPM Restu. Kriteria inklusi pada penelitian ini yaitu: ibu hamil yang bersedia mengikuti penelitian secara daring (online), dan kriteria eksklusinya yaitu: ibu hamil yang tidak memiliki Handphone android atau memiliki handphone namun tidak menggunakan aplikasi Whatsapp dan tidak bisa akses google form. Semua responden yang memenuhi kriteria inklusi dan eksklusi dijadikan responden. Penelitian dilaksanakan pada bulan April 2021. 
Data dikumpulkan melalui pengisian formulir online, biodata responden dan kuesioner kecemasan dengan alat ukur PASS (The perinatal anxiety screening scale). Pada kunjungan/minggu pertama responden diminta untuk mengisi form persetujuan menjadi responden dan mengisi biodata. Pada kunjungan/minggu ke dua ibu hamil sebagai responden diminta untuk mengisi kuesioner kecemasan. PASS adalah instrumen self-report yang dirancang untuk skrining masalah kecemasan pada wanita hamil. PASS terdiri dari 31 item pertanyaan. Kekhawatiran Berlebihan dan Ketakutan Khusus, Perfeksionisme, Kontrol dan Trauma, Kecemasan Sosial serta Kecemasan Akut dan Pengaturan merupakan empat domain yang diukur. Total skor 0-93, dengan klasifikasi 0-20 "tidak ada gejala"; 21 41 "kecemasan ringan-sedang" dan 42-93 "kecemasan berat" (Somerville et al., 2014). Analisa data yang digunakan adalah distribusi frekuensi, karakteristik responden, kecemasan pada ibu hamil dan uji Chie Square.

\section{Hasil dan Pembahasan}

Tabel 1. Karakteristik Responden

\begin{tabular}{|c|c|c|c|}
\hline \multirow{2}{*}{\multicolumn{2}{|c|}{ Karakteristik }} & \multicolumn{2}{|c|}{ Frekuensi Ibu Hamil } \\
\hline & & \multirow{2}{*}{$\begin{array}{c}\mathbf{N} \\
0\end{array}$} & \multirow{2}{*}{$\begin{array}{c}\% \\
0\end{array}$} \\
\hline Usia & $<20$ tahun & & \\
\hline & 20-30 tahun & 25 & 83 \\
\hline & 30-40 tahun & 5 & 17 \\
\hline & $>40$ tahun & 0 & 0 \\
\hline & Total & 30 & 100 \\
\hline \multirow[t]{5}{*}{ Pendidikan } & SD & 3 & 10 \\
\hline & SMP & 4 & 13 \\
\hline & SMA & 20 & 67 \\
\hline & PT & 3 & 10 \\
\hline & Total & 30 & 100 \\
\hline \multirow[t]{5}{*}{ Pekerjaan } & $\mathrm{ASN}$ & 1 & 4 \\
\hline & Swasta & 4 & 13 \\
\hline & IRT & 21 & 70 \\
\hline & Lain-lain & 4 & 13 \\
\hline & Total & 30 & 100 \\
\hline \multirow[t]{6}{*}{ Kehamilan ke } & 1 & 18 & 60 \\
\hline & 2 & 6 & 20 \\
\hline & 3 & 6 & 20 \\
\hline & 4 & 0 & 0 \\
\hline & $>=5$ & 0 & 0 \\
\hline & Total & 30 & 100 \\
\hline \multirow[t]{4}{*}{ Usia Kehamilan } & $1-3$ bulan & 10 & 33 \\
\hline & 3- 6 bulan & 12 & 40 \\
\hline & 7-9 bulan & 8 & 27 \\
\hline & Total & 30 & 100 \\
\hline
\end{tabular}

Karakteristik responden pada tabel 1, yaitu mayoritas usia responden yaitu 20-30 tahun, berpendidikan SMA, pekerjaan sebagai ibu rumah tangga, dan hamil pertama pada trimester 2 atau usia kehamilan 4-6 bulan.

Tabel 2. Distribusi Frekuensi kecemasan pada Ibu Hamil

\begin{tabular}{lcc}
\hline \multirow{2}{*}{\multicolumn{1}{c}{ Level Kecemasan }} & \multicolumn{2}{c}{ Ibu Hamil } \\
\cline { 2 - 3 } & $\mathbf{N}$ & $\mathbf{\%}$ \\
\hline Tidak bergejala & 8 & 26 \\
Ringan - sedang & 20 & 67 \\
Berat & 2 & 7 \\
\hline Total & 30 & 100 \\
\hline
\end{tabular}


Hasil penelitian pada tabel 2 menunjukkan bahwa, 67 \% ibu hamil di BPM Restu Pakis Malang mengalami kecemasan dari skala ringan-sedang. Hasil tersebut menggambarkan bahwa sebagian besar ibu hamil di BPM Restu Pakis Malang mengalami kecemasan. Terdapat studi yang menyatakan bahwa komplikasi pada ibu hamil yang terdiagnosa COVID-19 lebih rendah tingkat kematiannya dibanding SARS atau MERS, namun terdapat komplikasi pada janin yaitu keguguran (2\%), hambatan pertumbuhan intrauterin (IUGR; 10\%), dan kelahiran prematur (39\%) (Lim et al., 2020). Hal ini menunjukkan bahwa ibu hamil yang mengalami kecemasan pada masa pandemi COVID-19 perlu pengelolaan yang efektif dan efisien agar menjelang persalinan semua tahap dapat dilalui dengan baik dan tanpa hambatan. Salah satu penelitian melaporkan beberapa kondisi yang sering menyebabkan stres terkait wabah COVID-19 pada ibu hamil yaitu kunjungan periksa kehamilan di rumah sakit $(72,65 \%)$, cara perlindungan dari COVID-19 (60,17\%), berita-berita yang beredar di social media (52, $14 \%)$, keselamatan bayi $(52,14)$, pengaruh COVID-19 terhadap janin $(45,76 \%)$ dan hasil kehamilan $(44,92)$ serta keamanan untuk menyusui (44,44\%) (Nanjundaswamy et al., 2020). Kejadian pandemi COVID19 secara umum dapat berdampak pada kekhawatiran ibu hamil dalam menjalani kehamilannya. Sehingga penanganan yang baik diharapkan dapat meminimalkan dampak negatif pada kesehatan ibu dan janin.

Tabel 3. Tabulasi Silang Karakteristik dengan Tingkat Kecemasan

\begin{tabular}{|c|c|c|c|c|c|c|c|}
\hline \multirow[t]{3}{*}{ Karakteristik } & \multicolumn{6}{|c|}{ Tingkat Kecemasan } & \multirow{3}{*}{ P value } \\
\hline & \multicolumn{2}{|c|}{ Tidak bergejala } & \multicolumn{2}{|c|}{ Ringan-sedang } & \multicolumn{2}{|c|}{ berat } & \\
\hline & $\mathbf{N}$ & $\mathbf{F}$ & $\mathbf{N}$ & $\mathbf{F}$ & $\mathbf{N}$ & $\mathbf{F}$ & \\
\hline Usia & & & & & & & 0,657 \\
\hline$<20$ tahun & 0 & 0 & 0 & 0 & 0 & 0 & \\
\hline 20-30 tahun & 6 & $20 \%$ & 17 & $56 \%$ & 2 & $7 \%$ & \\
\hline 30-40 tahun & 2 & $7 \%$ & 3 & $10 \%$ & 0 & 0 & \\
\hline$>40$ tahun & 0 & 0 & 0 & 0 & 0 & 0 & \\
\hline Pekerjaan & & & & & & & 0,001 \\
\hline IRT & 4 & $14 \%$ & 17 & $57 \%$ & 0 & 0 & \\
\hline Swasta & 1 & $3 \%$ & 2 & $7 \%$ & 1 & $3 \%$ & \\
\hline ASN & 0 & 0 & 0 & 0 & 1 & $3 \%$ & \\
\hline Lain-lain & 3 & $10 \%$ & 1 & $3 \%$ & 0 & 0 & \\
\hline Pendidikan & & & & & & & 0,011 \\
\hline SD & 0 & 0 & 2 & $7 \%$ & 1 & $3 \%$ & \\
\hline SMP & 1 & $3 \%$ & 2 & $7 \%$ & 1 & $3 \%$ & \\
\hline SMA & 4 & $14 \%$ & 16 & $53 \%$ & 0 & 0 & \\
\hline PT & 3 & $10 \%$ & 0 & 0 & 0 & 0 & \\
\hline Paritas & & & & & & & 0,000 \\
\hline Primipara & 6 & $20 \%$ & 16 & $53 \%$ & 2 & $7 \%$ & \\
\hline Multipara & 2 & $7 \%$ & 4 & $13 \%$ & 0 & 0 & \\
\hline Grandepara & 0 & 0 & 0 & 0 & 0 & 0 & \\
\hline UK & & & & & & & 0,874 \\
\hline TM I & 3 & $10 \%$ & 7 & $23 \%$ & 0 & 0 & \\
\hline TM II & 3 & $10 \%$ & 8 & $27 \%$ & 1 & $3 \%$ & \\
\hline TM III & 2 & $7 \%$ & 5 & $17 \%$ & 1 & $3 \%$ & \\
\hline
\end{tabular}

Tabel 3 menunjukkan yang mempengaruhi tingkat kecemasan ibu hamil adalah paritas. Hasil penelitian primipara paling mempengaruhi psikologi ibu pada pandemik yaitu 6 orang tidak bergejala (20\%), 16 orang dengan tingkat kecemasan sedang (53\%), orang berat yaitu (7\%). Hal ini sejalan dengan penelitian sebelumnya jika ibu bersalin dengan primigravida belum memiliki bayangan mengenai apa yang akan terjadi selama persalinan dan dalam menghadapi adapatasi kebiasaan baru terkait covid-19 masih belum tahu bagaimana cara menyikapi pandemik ini (Usia et al., 2021) . 
Pada kunjungan antenatal selama masa pandemi, baik langsung atau daring, diharapkan pengkajian psikologis ibu hamil dilaksanakan dengan lebih optimal, ada beberapa hal juga yang perlu untuk diperhatikan seperti meningkatkan dukungan dari keluarga terhadap kondisi ibu sehingga dapat mengurangi dampak dari stres terhadap sistem imun (Ulya, 2019). Terdapat bukti jika dukungan sosial pada saat dalam situasi kecemasan dapat meningkatkan imun tubuh. (Baron et al., 1990). Perlunya aktivitas jasmani bagi ibu hamil. Penurunan stres dan kecemasan pada ibu hamil memiliki hubungan dengan aktivitas jasmani (Poon et al., 2020). Membatasi konsumsi berita -berita seputar pandemik yang tidak benar. Agar dapat menyesuaikan diri dengan perubahan yang terjadi maka ibu perlu untuk mempersiapkan diri. Konsultasi dengan profesional diperlukan jika kondisi tidak berubah membaik (Rosyida, 2019). Keterbatasan dalam penelitian ini adalah pada pemilihan sampel ibu hamil hanya dari satu klinik BPM saja, sehingga kurang memberikan gambaran ibu hamil di wilayah yang lebih luas. Dalam penelitian ini tidak ada konflik kepentingan dari pihak manapun (Yunita \& Angin, 2020).

\section{Kesimpulan}

Ibu hamil di BPM Restu Pakis Malang, pada masa pandemi COVID-19 ini sebagian besar ibu hamil mengalami tingkat kecemasan dengan skala ringan-sedang.

\section{Daftar Pustaka}

Baron, R. S., Cutrona, C. E., Hicklin, D., Russell, D. W., \& Lubaroff, D. M. (1990). Social support and immune function among spouses of cancer patients. Journal of Personality and Social Psychology, 59(2), 344-352. https://doi.org/10.1037//0022-3514.59.2.344

Corbett, G. A., Milne, S. J., \& Hehir, M. P. (2020). HEALTH ANXIETY AND BEHAVIOURAL CHANGES OF PREGNANT WOMEN DURING THE COVID-19 PANDEMIC. Elsivieri, January.

Durankuş, F., \& Aksu, E. (2020). Effects of the COVID-19 pandemic on anxiety and depressive symptoms in pregnant women: a preliminary study. Journal of Maternal-Fetal and Neonatal Medicine, O(0), 1-7. https://doi.org/10.1080/14767058.2020.1763946

Keputusan Presiden Republik Indonesia No 7 Tahun 2020 Tentang Gugus Tugas Percepatan Penanganan COVID-19 di Indonesia.

Lim, L. M., Li, S., Biswas, A., \& Choolani, M. (2020). Coronavirus disease 2019 (COVID-19) pandemic and pregnancy. The American Journal of Obstetrics \& Gynecology, 222(6), 521-531.

Nanjundaswamy, M. H., Shiva, L., Desai, G., Ganjekar, S., Kishore, T., Ram, U., Satyanarayana, V., Thippeswamy, H., \& Chandra, P. S. (2020). COVID-19-related anxiety and concerns expressed by pregnant and postpartum women - a survey among obstetricians. Archives of Women's Mental Health, 23(6), 787-790. https://doi.org/10.1007/s00737-020-01060-w

Nurhasanah, I. (2020). FAKTOR YANG MEMPENGARUHI KECEMASAN PADA IBU HAMIL SAAT PANDEMI COVID-19 : LITERATUR REVIEW. Jurnal Bidan Komunitas, 4(1).

Phoswa, W. N., \& Khaliq, O. P. (2020). Is pregnancy a risk factor of COVID-19? January.

Poon, L. C., Yang, H., Kapur, A., Melamed, N., Dao, B., Divakar, H., McIntyre, H. D., Kihara, A. B., Ayres-de-Campos, D., Ferrazzi, E. M., Di Renzo, G. C., \& Hod, M. (2020). Global interim guidance on coronavirus disease 2019 (COVID-19) during pregnancy and puerperium from FIGO and allied partners: Information for healthcare professionals. International Journal of Gynaecology and Obstetrics: The Official Organ of the International Federation of Gynaecology and Obstetrics, 149(3), 273-286. https://doi.org/10.1002/ijgo.13156 
Rosyida, D. A. C. (2019). Psikologi Ibu Dan Anak (1st ed.). Refika Aditama. http://perpustakaan.uinantasari.ac.id/opac/index.php?p=show_detail\&id=20744

Saputri, I. S., Yudianti, I., Kebidanan, J., Kesehatan, P., \& Malang, K. (2020). Anxiety Level Of Third Trimester Pregnant Women. JURNAL Midwifery Update (MU), 8511, 16-23.

Somerville, S., Dedman, K., Hagan, R., Oxnam, E., Wettinger, M., Byrne, S., Coo, S., Doherty, D., \& Page, A. C. (2014). The Perinatal Anxiety Screening Scale: development and preliminary validation. Archives of Women's Mental Health, 17(5), 443-454. https://doi.org/10.1007/s00737014-0425-8

Ulya, F. hikmatul. (2019). Pengaruh Rendam Kaki Dengan Air Hangat Terhadap Tingkat Kecemasan Pada Ibu Hamil. Embrio, 11(2), 80-86. https://doi.org/10.36456/embrio.vol11.no2.a2044

Usia, H., Dan, P., Keluarga, D., Kecemasan, D., Bersalin, I. B. U., \& Di, K. I. (2021). Bersalin Esti Husada Semarang Correlation Age, Parity, Education and Family Support With. 7, 1-6.

Wu, Y., Zhang, C., Liu, H., Duan, C., Li, C., Fan, J., Li, H., Chen, L., Xu, H., Li, X., Guo, Y., Wang, Y., Li, X., Li, J., Zhang, T., You, Y., Li, H., Yang, S., Tao, X., ... Huang, H.-F. (2020). Perinatal depressive and anxiety symptoms of pregnant women during the coronavirus disease 2019 outbreak in China. American Journal of Obstetrics and Gynecology, 223(2), 240.e1-240.e9. https://doi.org/10.1016/j.ajog.2020.05.009

Yunita, S., \& Angin, P. (2020). Pengaruh Tingkat Kecemasan dan Mekanisme Koping Ibu Primigravida terhadap Lamanya Kala I Persalinan Spontan The Effect of Anxiety Levels and Coping Mechanism of The Primigravida Against the Length of First Stage of Spontant Labor. 12(Nov). 